\title{
Fatty acid profile of milk and Cacioricotta cheese from Italian Simmental cows as affected by dietary flaxseed supplementation
}

\author{
A. Santillo, ${ }^{1}$ M. Caroprese, R. Marino, F. d'Angelo, A. Sevi, and M. Albenzio \\ Department of the Sciences of Agriculture, Food and Environment (SAFE), University of Foggia, Via Napoli, 25, 71122 Foggia, Italy
}

\begin{abstract}
The study aimed to determine the effects of adding flaxseed to the diet on the fatty acid profile of the milk of Italian Simmental cows and on the Cacioricotta cheese thereby produced. The experiment involved 24 Italian Simmental cows divided into 2 groups of 12 animals according to the diet fed: a control diet $(\mathrm{CO})$ with no flaxseed supplementation, and a diet supplemented with whole flaxseed (FS). Milk yield and composition was not significantly changed by diet, whereas saturated fatty acids, monounsaturated fatty acids (MUFA), and polyunsaturated fatty acids (PUFA) were increased by flaxseed supplementation. Cows fed flaxseed showed higher percentages of long-chain fatty acids: in particular, linolenic acids, mainly represented by $\mathrm{C} 18: 3 \mathrm{n}-3$, and n-3 series were higher in the FS group than in the CO group. The percentage of MUFA was higher by about $12 \%$ in FS than in CO, mainly due to the contribution of $\mathrm{C} 18: 1$ cis-9. The percentage of conjugated linoleic acid (CLA) in milk was not significantly changed by flaxseed supplementation. Furthermore, atherogenic and thrombogenic indices were lower by about 30 and $16 \%$, respectively, in the FS group compared with the $\mathrm{CO}$ group. The fatty acid profile of Cacioricotta cheese produced using Italian Simmental cow milk showed higher levels of MUFA, PUFA, and n-3, and improved atherogenic and thrombogenic indices in FS than in $\mathrm{CO}$, confirming the ability to transfer beneficial molecules from milk into cheese. In particular, cheesemaking technology contributed to the increased CLA content in Cacioricotta cheese.
\end{abstract}

Key words: flaxseed, Italian Simmental cow, fatty acid, Cacioricotta cheese

\section{INTRODUCTION}

Milk fat contains substantial concentrations of SFA and relatively low concentrations of MUFA and PUFA;

Received September 18, 2015

Accepted December 17, 2015.

${ }^{1}$ Corresponding author: antonella.santillo@unifg.it therefore, it has been criticized because it contains a less desirable balance of fatty acids than vegetable fat or fish oil (Kennelly, 1996). Health-conscious consumers have gained awareness that MUFA and PUFA are healthier than SFA; in particular, research has shown several health benefits of n-3 fatty acids (including $\alpha$-linolenic acid) to humans, including a decrease in the incidence of cancer, cardiovascular diseases, hypertension, and arthritis and an improvement in visual ability (Simopoulos, 1996; Wright et al., 1998). Therefore, consumer demand today is oriented toward dairy products with a valuable fatty acids profile to meet their health concerns.

In recent years, several experiments conducted on dairy cows have shown that a supplementation of oilseeds (rich in n-3 fatty acids) such as flaxseed, rapeseed, or soybean is an effective strategy for improving the nutritional value of milk fat (Shingfield et al., 2008) through an increase of the levels of PUFA and MUFA. Few studies have investigated the fatty acid profile of cheese made from milk produced from livestock receiving oilseed supplementation; the majority have involved cheese from small ruminant milk (Luna et al., 2005; Nudda et al., 2005; Gòmez-Cortés et al., 2009, Mele et al., 2011) whereas less research has been conducted on cheese produced from Friesian cows fed oilseeds (Dhiman et al., 1999; Caroprese et al., 2013; Cattani et al., 2014).

Several factors play a role in the efficiency with which milk components are transferred into cheese, and these are related to the feeding regimen of the animals (Banks et al., 1986), milk features, and cheese-making conditions (Lucey and Kelly, 1994). In particular, milkprocessing temperature may affect lipid composition of cheese; high processing temperatures and addition of whey protein concentrates have been found to increase the formation of CLA in the processed cheese as the result of oxidation processes (Shantha et al., 1992; Garcia-Lopez et al., 1994). In southern Italy, a typical and traditional cheese is Cacioricotta cheese, which is usually produced from goat milk; this type of cheese is made using an unusual technology - a high heat treatment at $90^{\circ} \mathrm{C}$ of whole milk that allows the recovery 
of whey proteins in the curd, giving high cheese yields (Albenzio et al., 2006).

To the best of our knowledge, no studies have been reported on the production of Cacioricotta cheese from bovine milk. It is unclear whether the unusual cheesemaking technology could affect the transfer of valuable nutritional fat components of milk into Cacioricotta cheese. In the light of this, the present paper aimed to evaluate the effects of flaxseed supplementation on the composition and the fatty acid profile of milk and Cacioricotta cheese from Italian Simmental cows.

\section{MATERIALS AND METHODS}

\section{Experimental Design}

The experiment was conducted in June and July 2014 in a dairy farm located in Cisternino (Brindisi, Apulian region, Italy). The experiment involved 24 Italian Simmental cows during mid lactation (175 \pm 12 DIM); animals were homogeneous for age ( $46 \pm 6$ mo), BW $(475 \pm 18 \mathrm{~kg})$, BCS $(3.68 \pm 0.5)$, parity $(2.58$ $\pm 0.28)$, milk production $(19.8 \pm 0.80 \mathrm{~kg} / \mathrm{d})$, milk fat content $(3.72 \pm 0.5 \%)$, milk protein content $(3.35 \pm$ $0.1 \%$ ), and fatty acid composition. Animals were assigned randomly to 1 of 2 groups subjected to different diets: (1) the control group (CO) received a diet based on $9.5 \mathrm{~kg}$ of concentrate mainly constituted by corn $(51 \%)$, soy $(22 \%)$, barley flour $(4 \%)$, and bran $(4.8 \%)$, $5 \mathrm{~kg}$ of corn grains, and $6.5 \mathrm{~kg}$ of vetch and oat hay; (2) the flaxseed group (FS) received the same diet but $1 \mathrm{~kg}$ of concentrate was substituted with the same amount of whole flaxseed (Lin Tech, Tecnozoo srl, Torreselle di Piombino Dese, Italy). The chemical composition of the diets is reported in Table 1.

Table 1. Ingredient and chemical composition of the experimental diets (\% on DM basis)

\begin{tabular}{lrr}
\hline & \multicolumn{2}{c}{ Diet $^{1}$} \\
\cline { 2 - 3 } Item & $\mathrm{CO}$ & $\mathrm{FS}$ \\
\hline Concentrate & 45.00 & 40.24 \\
Corn & 24.00 & 24.00 \\
Vetch and oat hay & 31.00 & 31.00 \\
Whole flaxseed & - & 4.76 \\
Ether extract & 2.67 & 4.72 \\
$\mathrm{CP}$ & 15.38 & 15.41 \\
$\mathrm{ADF}$ & 25.43 & 25.45 \\
$\mathrm{NDF}$ & 42.60 & 42.48 \\
$\mathrm{ADL}$ & 3.34 & 3.45 \\
$\mathrm{NE}_{\mathrm{L}}{ }^{2}(\mathrm{Mcal} / \mathrm{kg})$ & 1.56 & 1.68 \\
\hline
\end{tabular}

${ }^{1} \mathrm{CO}=$ control group; FS = flaxseed group.

${ }^{2}$ Calculated according to NRC (2001).
The experiment lasted $7 \mathrm{wk}$; the first $2 \mathrm{wk}$ were considered an adaptation period and measurements were made during the last 5 wk. Cows were housed in strawbedded barns with free access to water and were fed twice daily (at 0800 and $1600 \mathrm{~h}$ ). The total amount of flaxseed was given before the morning feeding to each cow of the FS group and we verified that each animal consumed the total quantity of supplement given. Cows were milked mechanically twice daily at 0600 and 1800 $\mathrm{h}$, and milk production was recorded at each milking. Milk collection was done once a week on the same day throughout the experiment. Individual milk samples were obtained by mixing milk from the morning and afternoon milkings in an amount proportional to milk yield. Individual milk samples were stored under refrigeration and transferred to the laboratory for analyses.

At the end of the wk 6 and 7 of the experiment, bulk milk was collected and pooled from the evening and morning milkings from each experimental group. Pooled milk from each group was divided into 2 aliquots and processed to Cacioricotta cheese using the following protocol: raw milk was heated at $90^{\circ} \mathrm{C}$, held for $2 \mathrm{~min}$, and then cooled to $40^{\circ} \mathrm{C}$. Then, $1 \%$ of saturated brine $\left(23 \% \mathrm{NaCl}, 0.06 \% \mathrm{CaCl}_{2}\right)$ was added. Subsequently, 150 g/100 L of rennet (Chr. Hansen s.p.a., Parma, Italy) containing $77 \%$ chymosin was added, and curdling was obtained in about $10 \mathrm{~min}$. The subsequent steps were cutting of the coagulum to rice-grain size, putting the curd into reed containers, and manual pressing of the curd to facilitate the draining off of the whey. The curd was held at controlled temperature $\left(22^{\circ} \mathrm{C}\right)$ for $24 \mathrm{~h}$, dry-salted for $1 \mathrm{~d}$, and then ripened for $7 \mathrm{~d}$ at $12^{\circ} \mathrm{C}$ and $80 \%$ relative humidity. At the end of the ripening time, cheeses were transferred to the laboratory under refrigeration, and 3 cheeses from each cheese-making were analyzed in triplicate.

\section{Analyses of Milk}

Individual and bulk milk samples were analyzed for fat, protein, casein, and lactose contents (MilkoScan FT 120; Foss Electric A/S, Hillerød, Denmark), and SCC (Fossomatic Minor, Foss-Electric A/S). Individual and bulk milk renneting characteristics (clotting time, rate of clot formation, and clot firmness after $30 \mathrm{~min}$ ) were measured using a Formagraph (Foss Electric A/S).

Fatty acids extraction from milk samples was performed as described by Feng et al. (2004), with some modifications. Briefly, $30 \mathrm{~mL}$ of bulk milk was centrifuged at $17,800 \times g$ for $45 \mathrm{~min}$ at $4^{\circ} \mathrm{C}$. Then, $1.0 \mathrm{~g}$ of the fat layer was transferred into a microtube, left at room temperature for $30 \mathrm{~min}$, and centrifuged at 19,300 $\times g$ for $40 \mathrm{~min}$ at $20^{\circ} \mathrm{C}$. Fatty acids methyl esters were 
obtained as described in IDF (2002); $100 \mathrm{mg}$ of the upper layer was placed into a $16-\times 25$-mm screw-capped Pyrex tube to which $5 \mathrm{~mL}$ of hexane and $0.2 \mathrm{~mL}$ of 2 $N$ methanolic $\mathrm{KOH}$ were added. The tube was vortexed and left to stand for $5 \mathrm{~min}$ in the dark; then, $0.5 \mathrm{~g}$ of $\mathrm{NaHSO}_{4} \cdot \mathrm{H}_{2} \mathrm{O}$ was added. The hexane layer, containing the FAME, was placed into a GC vial. The vial was capped and placed at $-20^{\circ} \mathrm{C}$ until $\mathrm{GC}$ analysis. The fatty acid composition of milk extracts was determined by capillary GC on a HP-88, $100 \mathrm{~m} \times 0.25 \mathrm{~mm} \times 0.20$ $\mu \mathrm{m}$ capillary column (Agilent Technologies Inc., Santa Clara, CA) installed on an Agilent Technologies 6890N gas chromatograph equipped with a flame-ionization detector and a split injection. The initial oven temperature was $70^{\circ} \mathrm{C}$, held for $4 \mathrm{~min}$, subsequently increased to $175^{\circ} \mathrm{C}$ at a rate of $13^{\circ} \mathrm{C} \mathrm{min}{ }^{-1}$, and held for $27 \mathrm{~min}$, increased to $215^{\circ} \mathrm{C}$ at a rate of $4^{\circ} \mathrm{C} \min ^{-1}$, and then held for $45 \mathrm{~min}$. Helium was used as the carrier gas and the column head pressure was $175 \mathrm{kPa}$. Both the injector and the detector were set at $250^{\circ} \mathrm{C}$. The split ratio was 20:1. Fatty acids were identified by comparing their retention times with the fatty acid methyl standards (FIM-FAME-7-Mix, Matreya LLC, Pleasant Gap, PA), and C18:1 trans-11, C18:2 cis-9,trans-11, C18:2 cis-9,cis-11, C18:2 trans-9,trans-11, and C18:2 trans-10,cis-12 (Matreya LLC) and peak areas were quantified using Agilent Chemstation software.

Atherogenic and thrombogenic indices were calculated according to formulas from Ulbricht and Southgate (1991): atherogenic index $=(\mathrm{C} 12: 0+4 \times \mathrm{C} 14: 0+$ C16:0)/ $\Sigma$ MUFA $+\Sigma$ PUFA(n-6) and (n-3)]; thrombogenic index $=(\mathrm{C} 14: 0+\mathrm{C} 16: 0+\mathrm{C} 18: 0) /[0.5 \times \Sigma$ MUFA $+0.5 \times \Sigma$ PUFA(n-6) $+3 \times \Sigma$ PUFA(n-3) + $(\mathrm{n}-3) /(\mathrm{n}-6)]$.

\section{Analyses of Cacioricotta Cheese}

The DM content of cheese was determined according to International Dairy Federation method (IDF, 1986). Total nitrogen was determined as described by Gripon et al. (1975), and fat was determined by the Soxhlet method using diethyl ether.

Extraction of fatty acids from cheese samples was performed as described by O'Fallon et al. (2007). Briefly, $1.0 \mathrm{~g}$ of sample was placed into a $16-\times 125-$ mm screw-capped Pyrex tube to which C13:0 internal standard (0.5 mg of C13:0/mL of methanol), $0.7 \mathrm{~mL}$ of $10 \mathrm{~N} \mathrm{KOH}$, and $5.3 \mathrm{~mL}$ of methanol were added. The tube was incubated in a $55^{\circ} \mathrm{C}$ water bath for $1.5 \mathrm{~h}$ with shaking by hand every $20 \mathrm{~min}$. After cooling the tube below room temperature, $0.58 \mathrm{~mL}$ of $24 \mathrm{~N} \mathrm{H}_{2} \mathrm{SO}_{4}$ was added. The tube was mixed by inversion and incubated again in a $55^{\circ} \mathrm{C}$ water bath for $1.5 \mathrm{~h}$ with shaking by hand every $20 \mathrm{~min}$. Then, the tube was cooled in a cold tap water bath, $3 \mathrm{~mL}$ of hexane was added, and the tube was vortexed for $5 \mathrm{~min}$. The tube was then centrifuged at $500 \times g$ for $5 \mathrm{~min}$, and the hexane layer, containing the FAME, was placed into a GC vial. The vial was capped and placed at $-20^{\circ} \mathrm{C}$ until GC analysis according to the previous method described for milk extracts.

\section{Statistical Analysis}

All variables were tested for normality using the Shapiro-Wilk test (Shapiro and Wilk, 1965). Data were processed using ANOVA for repeated measures (SAS Institute, 2011), with flaxseed supplementation, time of sampling, and their interactions as repeated factors. Where significant effects were found $(P<0.05)$, Student's $t$-test was used to locate significant differences between means. The interaction of treatment and time was not significant for milk yield, milk and cheese composition, or for fatty acid content of milk and cheese; therefore, mean values for the mentioned parameters are presented.

\section{RESULTS AND DISCUSSION}

The chemical composition of milk obtained from Italian Simmental cows subjected to different diets was not significantly influenced by flaxseed supplementation. Mean percentages of fat, protein, lactose, and casein were $3.9 \pm 0.5,3.2 \pm 0.1,4.8 \pm 0.1$, and $2.5 \pm 0.1 \%$ respectively. Milk yield was not affected by diet although it exhibited a lower value in the FS group $(24.06 \pm 1.2 \mathrm{~kg} / \mathrm{d})$ than in the CO group $(26.68$ $\pm 1.2 \mathrm{~kg} / \mathrm{d}$ ). Gonthier at al. (2005) also found that cows fed flaxseed diets produced $1.8 \mathrm{~kg}$ less milk than those fed the control diet although differences were not significant; moreover, diet supplementation with whole flaxseed generally has little effect on milk production of cows in the mid stage of lactation (Petit, 2010). The effect of linseed supplementation on milk components is still controversial although several studies have reported that flaxseed supplementation did not change either the fat (Gonthier et al., 2005) or the protein concentration of milk (Petit et al., 2004; Martin et al., 2008). Somatic cell count was not influenced by the tested diets, and the mean values detected in $\mathrm{CO}$ and FS groups were $126.4 \pm 23.19$ and $127.22 \pm 22.13 \times 10^{3}$ cells/mL of milk, respectively. Milk SCC has generally not been affected by flaxseed supplementation (Martin et al., 2008) although few data have been published on this topic. Some evidence suggests that feeding plant oils rich in n-3 fatty acids alters the production 
of cytokines and functional properties of macrophages, lymphocytes, and other immunocompetent cells as shown by a reduced proliferative response of activated peripheral blood mononuclear cells of dairy cows fed whole flaxseed (Lessard et al., 2003).

Milk coagulating ability was studied by measuring coagulation time, rate of clot formation, and clot firmness, which were not influenced by the tested effect: coagulation time was $11.34 \pm 0.58(\mathrm{CO})$ and $10.8 \pm$ $0.47 \mathrm{~min}$ (FS); rate of clot formation was $3.97 \pm 0.38$ $(\mathrm{CO})$ and $3.62 \pm 0.32 \mathrm{~min}(\mathrm{FS})$; and curd firmness after 30 min was $28.14 \pm 1.65(\mathrm{CO})$ and $29.37 \pm 1.42$ $\mathrm{mm}$ (FS).

Mean values of fatty acids in milk from cows subjected to flaxseed supplementation are presented in Table 2. Short-, medium-, and long-chain fatty acids were influenced by diet, confirming that supplemental fats in the diet are able to influence fatty acid percentages in milk fat (Caroprese et al., 2010). In particular, all fatty acids ranging from $\mathrm{C} 4: 0$ to $\mathrm{C} 12: 0$ were lower in FS than in CO, whereas of the medium-chain fatty acids, only C14:0 and C16:0 were lower in the FS group. It has been reported that long-chain fatty acids are powerful inhibitors of acetyl-CoA carboxylase (Chilliard and Ferlay, 2004) involved in the de novo synthesis of milk fat; supplemental PUFA have been shown to reduce the concentrations of short- and medium-chain fatty acids in milk (Zhang et al., 2006). Focusing on the long-chain fatty acid group, the linolenic acids, mainly represented by C18:3n-3, were about $33 \%$ higher in FS than in $\mathrm{CO}$ and were derived from the increased supply of dietary long-chain fatty acids. It is reported that C18:3n-3 acid (representing about $55 \%$ of fatty acids in flaxseed) induces a large number of intermediaries, but CLA cis-9,trans-11 production does not seem to occur (Petit, 2010). Conjugated linoleic acid synthesis is attributed to biohydrogenation by ruminal bacteria, especially Butyrivibrio fibrisolvens, and later to the uptake of intermediates from the udder, which are desaturated by $\Delta^{9}$-desaturase. Contents of CLA were numerically, if not significantly, higher in milk from cows fed flaxseed supplementation, according to Cattani et al. (2014). Also, C18:1 trans-11 and C18:2 were higher in the FS group, confirming the hypothesis that a complex system of intermediates and products of rumen biohydrogenation of PUFA is delivered by the fat supplement of the diet. Furthermore, higher levels of C18:0 and C18:1 cis-9 were found in milk from the FS group compared with the $\mathrm{CO}$ group. It has been reported that diets rich in vegetable oils or seeds lead to an increase in stearic acid produced in the rumen, which is then transformed, in part, into oleic acid in the udder (Chilliard and Ferlay, 2004).
Nutritional indices of milk from Italian Simmental cows subjected to different diets are presented in Table 3. Saturated fatty acids, MUFA, and PUFA were affected by diet, with SFA being lower and MUFA and PUFA being higher in FS than in CO; consequently, the ratio of PUFA to SFA was significantly higher in the same group. The MUFA and n-3 fatty acids were higher by about 12 and $24 \%$, respectively, in FS than in CO, mainly due to the contributions of C18:1 cis-9 and C18:3n-3. It is well known that the UFA, in particular C18:1 cis-9, and PUFA, including CLA, have a protective effect against cardiovascular diseases (Williams, 2000 ). The ratio of $n-6$ to $n-3$ was lower in the FS group, and the atherogenic and thrombogenic indices were lower by about 30 and $16 \%$, respectively, in the same group compared with the control milk. In a previous study, Caroprese et al. (2010) found that linseed supplementation in cow was able to lower the atherogenic index by $13 \%$ and the thrombogenic index by $8 \%$.

The chemical parameters of Cacioricotta cheeses from $\mathrm{CO}$ and FS groups did not differ significantly, and the mean values for moisture, protein, and fat contents were $67.29 \pm 0.16 \%, 29.9 \pm 0.2 \%$, and $24.68 \pm 0.58 \%$, respectively, after $7 \mathrm{~d}$ of ripening.

The fatty acid composition of Cacioricotta cheeses from milk of Italian Simmental cows subjected to different diets is reported in Table 4. In this study, C18:0,

Table 2. Mean fatty acid (FA) composition (\%) of milk from Italian Simmental cows subjected to different diets

\begin{tabular}{|c|c|c|c|c|}
\hline \multirow[b]{2}{*}{ FA/group } & \multicolumn{2}{|c|}{ Diet $^{1}$} & \multirow[b]{2}{*}{ SEM } & \multirow{2}{*}{$\frac{\text { Effect, } P \text {-value }}{\text { Treatment }}$} \\
\hline & $\mathrm{CO}$ & FS & & \\
\hline Short-chain $\mathrm{FA}^{2}$ & 16.130 & 14.380 & 0.170 & * \\
\hline $\mathrm{C} 4: 0$ & 5.181 & 4.891 & 0.121 & $* *$ \\
\hline C6:0 & 2.810 & 2.582 & 0.062 & $*$ \\
\hline C8:0 & 1.534 & 1.353 & 0.043 & $*$ \\
\hline C10:0 & 3.232 & 2.750 & 0.131 & $*$ \\
\hline C12:0 & 3.481 & 2.942 & 0.142 & * \\
\hline Medium-chain $\mathrm{FA}^{3}$ & 43.940 & 40.680 & 0.300 & * \\
\hline C14:0 & 11.93 & 10.4 & 0.36 & $*$ \\
\hline C16:0 & 28.33 & 26.62 & 0.54 & $*$ \\
\hline Long-chain $\mathrm{FA}^{4}$ & 39.439 & 44.828 & 0.100 & $*$ \\
\hline C18:0 & 11.560 & 12.860 & 0.340 & $* * *$ \\
\hline C18:1 cis-9 & 22.600 & 25.020 & 0.680 & $* *$ \\
\hline $\mathrm{C} 18: 1$ trans & 0.710 & 1.160 & 0.070 & ** \\
\hline C18:2 & 2.760 & 3.160 & 0.060 & ** \\
\hline $\mathrm{C} 18: 3$ & 0.66 & 0.99 & 0.003 & $* *$ \\
\hline CLA & 0.153 & 0.169 & 0.04 & NS \\
\hline
\end{tabular}

${ }^{1} \mathrm{CO}=$ control group; FS $=$ flaxseed group.

${ }^{2} \mathrm{Sum}$ of $\mathrm{C} 4: 0$ to C13:0.

${ }^{3}$ Sum of $\mathrm{C} 14: 0$ to $\mathrm{C} 17: 1$.

${ }^{4}$ Longer than $\mathrm{C} 17 ; \mathrm{C} 18: 1$ trans $=$ sum of $\mathrm{C} 18: 1$ trans -9 and $\mathrm{C} 18: 1$ trans-11; $\mathrm{C} 18: 2=$ sum of $\mathrm{C} 18: 2$ trans -9, trans -12 and $\mathrm{C} 18: 2$ cis9, cis-12; C18:3 = sum of C18:3n-3 and C18:3n-6; CLA = sum of CLA cis-9,trans-11, CLA trans-10,cis-12, and CLA trans-9,trans-11.

${ }^{*} P<0.05,{ }^{* *} P<0.01,{ }^{* * *} P<0.001$. 
Table 3. Saturated fatty acids, MUFA, PUFA, n-6, and n-3 (\%), and principal nutritional indices of milk from Italian Simmental cows subjected to different diets

\begin{tabular}{lrrrrc}
\hline & \multicolumn{2}{c}{ Diet $^{2}$} & & \multirow{2}{*}{ Effect, $P$-value } \\
\cline { 2 - 3 } Item $^{1}$ & CO & FS & SEM & Treatment \\
\hline SFA & 64.660 & 60.330 & 1.170 & $* *$ \\
MUFA & 23.160 & 26.160 & 1.100 & $* *$ \\
PUFA & 4.431 & 5.872 & 0.171 & $*$ \\
PUFA:SFA & 0.070 & 0.080 & 0.003 & $* *$ \\
n-6 & 3.751 & 4.320 & 0.141 & $*$ \\
n-3 & 0.712 & 0.933 & 0.040 & $* *$ \\
n-6:n-3 & 5.240 & 4.712 & 0.190 & $* * *$ \\
Atherogenic index & 2.910 & 2.042 & 0.170 & $* *$ \\
Thrombogenic index & 3.310 & 2.770 & 0.130 & $* *$ \\
\hline
\end{tabular}

${ }^{1}$ Atherogenic index $(\mathrm{C} 12: 0+4 \times \mathrm{C} 14: 0+\mathrm{C} 16: 0) /[\Sigma \mathrm{MUFA}+\Sigma$ PUFA(n-6) and (n-3)]; thrombogenic index $=(\mathrm{C} 14: 0+\mathrm{C} 16: 0+$ C18:0) $/[0.5 \times \Sigma$ MUFA $+0.5 \times \Sigma$ PUFA(n-6) $+3 \times \Sigma$ PUFA(n-3) $+(\mathrm{n}-3) /(\mathrm{n}-6)]$.

${ }^{2} \mathrm{CO}=$ control group; $\mathrm{FS}=$ flaxseed group.

${ }^{*} P<0.05,{ }^{* *} P<0.01,{ }^{* * *} P<0.001$.

C18:1 cis-9, C18:2, C18:3n-3, and C22:1, were higher, whereas $\mathrm{C} 14: 0$ and $\mathrm{C} 16: 0$ were lower in FS cheese, demonstrating the potential to improve the cheese fatty acid profile by modulating the fat supplement of the diet in lactating cow. It is reported that the fat content of cheese is primarily influenced by the fat content of the original milk, whereas the cheese-making technology is considered to be of minor importance (Lucas et al., 2006).

Higher levels of CLA cis-9,trans-11 and CLA trans9, trans-11 were found in the FS cheese compared with the $\mathrm{CO}$ cheese, which was ascribed both to higher levels of precursors of CLA in the milk and to the processing technology of Cacioricotta cheese. Ha et al. (1989) proposed a mechanism for the formation of CLA in dairy products that involves free radical oxidation of linoleic or linolenic acid during cheese processing. In particular, the application of heat enhances the formation of linoleic acid radicals and increases CLA content during the production of natural and process cheeses (Shantha et al., 1992; Garcia-Lopez et al., 1994). The enhancement of CLA formation at elevated temperatures has been observed in preparing process cheese (Shantha et al., 1992; Garcia-Lopez et al., 1994) and ghee, an Indian clarified butter product (Aneja and Murthi, 1990). Cacioricotta cheese-making requires heating the milk to about $90^{\circ} \mathrm{C}$ to denature the whey proteins with the aim of entrapping them in the coagulum; therefore, the heating step could have played a role in the increase of CLA content in Cacioricotta cheese. Ha et al. (1989) reported that lactalbumin- and lactoglobulin-enriched cheeses contain significantly greater amounts of CLA compared with cheeses not enriched. Under the anaero- bic conditions occurring during cheese aging, oxidation of linoleic acid in glycerides or phospholipids may be initiated to form an allyl radical; the radical would be stabilized through the formation of its resonance form, which requires hydrogens to form a conjugated doublebond system.

The mean values of nutritional indices of Cacioricotta cheeses from milk of Italian Simmental cows subjected to different diets are reported in Table 5. Saturated fatty acid contents were lower, whereas contents of MUFA, PUFA, and n-3 were higher in cheese from the FS group compared with the CO group. Atherogenic and thrombogenic indices and the ratio of n- 6 to n- 3 were lower in FS, confirming the improvement of nutritional features of cheese obtained from milk of cows supplemented with flaxseed. In particular, the balance in the diet between n- 6 and n-3 PUFA is involved in the prevention of many diseases such as coronary artery disease (Williams, 2000). Moreover, C18:3n-3 and CLA represented valuable nutritional components in Cacioricotta cheese.

Table 4. Mean fatty acid composition (\%) of cheese from milk of Italian Simmental cows subjected to different diets

\begin{tabular}{|c|c|c|c|c|}
\hline \multirow[b]{2}{*}{ Fatty acid ${ }^{1}$} & \multicolumn{2}{|c|}{ Diet $^{2}$} & \multirow[b]{2}{*}{ SEM } & \multirow{2}{*}{$\frac{\text { Effect, } P \text {-value }}{\text { Treatment }}$} \\
\hline & $\mathrm{CO}$ & FS & & \\
\hline $\mathrm{C} 4: 0$ & 1.700 & 1.340 & 0.160 & NS \\
\hline C6:0 & 1.180 & 1.041 & 0.120 & NS \\
\hline $\mathrm{C} 8: 0$ & 0.820 & 0.751 & 0.060 & NS \\
\hline C10:0 & 2.100 & 1.940 & 0.100 & NS \\
\hline C12:0 & 2.784 & 2.590 & 0.070 & NS \\
\hline C14:0 & 11.140 & 10.570 & 0.140 & * \\
\hline C14:1 & 0.851 & 0.810 & 0.030 & NS \\
\hline C15:0 & 1.281 & 1.240 & 0.080 & NS \\
\hline $\mathrm{C} 16: 0$ & 30.460 & 29.170 & 0.110 & $* *$ \\
\hline C16:1 & 1.370 & 1.330 & 0.012 & NS \\
\hline $\mathrm{C} 17: 0$ & 0.681 & 0.652 & 0.006 & NS \\
\hline C18:0 & 12.120 & 13.021 & 0.260 & * \\
\hline $\mathrm{C} 18: 1$ trans -9 & 0.071 & 0.082 & 0.003 & NS \\
\hline $\mathrm{C} 18: 1$ trans -11 & 2.652 & 2.143 & 0.250 & NS \\
\hline C18:1 cis-9 & 25.210 & 27.430 & 0.090 & $* * *$ \\
\hline C18:2 & 2.800 & 3.142 & 0.020 & $*$ \\
\hline C20:0 & 0.200 & 0.210 & 0.009 & NS \\
\hline C18:3n-6 & 0.050 & 0.057 & 0.001 & NS \\
\hline C18:3n-3 & 0.490 & 0.751 & 0.004 & $* * *$ \\
\hline C20:1 & 0.140 & 0.070 & 0.003 & NS \\
\hline CLA & 0.574 & 0.916 & 0.013 & $* * *$ \\
\hline C20:2 & 0.012 & 0.011 & 0.001 & NS \\
\hline $\mathrm{C} 22: 1$ & 0.110 & 0.230 & 0.04 & $*$ \\
\hline C20:4 & 0.123 & 0.111 & 0.002 & NS \\
\hline C20:5 & 0.080 & 0.100 & 0.003 & NS \\
\hline
\end{tabular}

${ }^{1} \mathrm{C} 18: 2=$ sum of $\mathrm{C} 18: 2$ trans-9,trans-12 and $\mathrm{C} 18: 2$ cis- 9 , cis- $12 ; \mathrm{C} 18: 3$ $=$ sum of C18:3n-3 and C18:3n-6; CLA = sum of CLA cis-9,trans-11, CLA trans-10, cis-12, CLA trans-9,trans-11.

${ }^{2} \mathrm{CO}=$ control group; $\mathrm{FS}=$ flaxseed group

${ }^{*} P<0.05,{ }^{* *} P<0.01,{ }^{* * *} P<0.001$. 
Table 5. Saturated fatty acids, MUFA, PUFA, n-6, and n-3 (\%), and principal nutritional indices of cheese from milk of Italian Simmental cows subjected to different diets

\begin{tabular}{|c|c|c|c|c|}
\hline \multirow[b]{2}{*}{ Item $^{1}$} & \multicolumn{2}{|c|}{ Diet $^{2}$} & \multirow[b]{2}{*}{ SEM } & \multirow{2}{*}{$\frac{\text { Effect, } P \text {-value }}{\text { Treatment }}$} \\
\hline & $\mathrm{CO}$ & FS & & \\
\hline SFA & 62.681 & 61.223 & 0.180 & ** \\
\hline MUFA & 27.931 & 29.672 & 0.280 & * \\
\hline PUFA & 4.481 & 4.805 & 0.09 & $*$ \\
\hline PUFA:SFA & 0.070 & 0.070 & 0.002 & NS \\
\hline $\mathrm{n}-6$ & 3.900 & 3.960 & 0.09 & NS \\
\hline $\mathrm{n}-3$ & 0.612 & 0.902 & 0.010 & $* * *$ \\
\hline$n-6: n-3$ & 6.371 & 4.412 & 0.150 & $* * *$ \\
\hline Atherogenic index & 2.400 & 2.140 & 0.030 & $* *$ \\
\hline Thrombogenic index & 3.010 & 2.630 & 0.020 & $* * *$ \\
\hline
\end{tabular}

${ }^{1}$ Atherogenic index $(\mathrm{C} 12: 0+4 \times \mathrm{C} 14: 0+\mathrm{C} 16: 0) /[\Sigma \mathrm{MUFA}+\Sigma$ PUFA(n-6) and (n-3)]; thrombogenic index $=(\mathrm{C} 14: 0+\mathrm{C} 16: 0+$ $\mathrm{C} 18: 0) /[0.5 \times \Sigma$ MUFA $+0.5 \times \Sigma$ PUFA(n-6) $+3 \times \Sigma$ PUFA(n-3) $+(\mathrm{n}-3) /(\mathrm{n}-6)]$.

${ }^{2} \mathrm{CO}=$ control group; $\mathrm{FS}=$ flaxseed group.

${ }^{*} P<0.05,{ }^{* *} P<0.01,{ }^{* * *} P<0.001$.

\section{CONCLUSIONS}

Supplementation of flaxseed to Italian Simmental dairy cows did not affect milk or Cacioricotta cheese characteristics in terms of principal composition. However, PUFA from the flaxseed supplement influenced the fatty acid composition of milk, resulting in higher levels of C18:0, C18:1 cis-9, C18:2, and C18:3n-3. The improvement of the fatty acid profile of Cacioricotta cheese obtained from FS milk was ascribed to the improved fatty acid profile of the original milk. In particular, the increased levels of CLA in FS cheese were attributed to the heat treatment of the milk that led to the retention of whey proteins in the cheese curd.

\section{REFERENCES}

Albenzio, M., M. Caroprese, R. Marino, A. Muscio, A. Santillo, and A. Sevi. 2006. Characteristics of Garganica goat milk and Cacioricotta cheese. Small Rumin. Res. 64:35-44.

Aneja, R. P., and T. N. Murthi. 1990. Conjugated linoleic acid contents of Indian curds and ghee. Indian J. Dairy Sci. 43:231-238.

Banks, J. M., L. J. Clapperton, D. D. Muir, and K. Girdler. 1986. The influence of diet and breed of cow on the efficiency of conversion of milk constituents to curds in cheese manufacture. J. Sci. Food Agric. 37:461-468.

Caroprese, M., A. Marzano, R. Marino, G. Gliatta, A. Muscio, and A. Sevi. 2010. Flaxseed supplementation improves fatty acid profile of cow milk. J. Dairy Sci. 93:2580-2588.

Caroprese, M., A. Sevi, R. Marino, A. Santillo, A. Tateo, and M. Albenzio. 2013. Composition and textural properties of Mozzarella cheese naturally-enriched in polyunsaturated fatty acids. J. Dairy Res. 80:276-282.

Cattani, M., R. Mantovani, S. Schiavon, G. Bittante, and L. Bailoni. 2014. Recovery of n-3 polyunsaturated fatty acids and conjugated linoleic acids in ripened cheese obtained from milk of cows fed different levels of extruded flaxseed. J. Dairy Sci. 97:123-135.
Chilliard, Y., and A. Ferlay. 2004. Dietary lipids and forages interactions on cow and goat milk fatty acids composition and sensory properties. Reprod. Nutr. Dev. 44:467-492.

Dhiman, T. R., E. D. Helmink, D. J. McMahon, R. L. Fife, and M. W. Pariza. 1999. Conjugated linoleic acid content of milk and cheese from cows fed extruded oilseeds. J. Dairy Sci. 82:412-419.

Feng, S., A. L. Lock, and P. C. Garnsworthy. 2004. A rapid method for determining fatty acid composition of milk. J. Dairy Sci. $87: 3785-3788$.

Garcia-Lopez, S., E. Echeverria, I. Tsui, and B. Balch. 1994. Changes in the content of conjugated linoleic acid (CLA) in processed cheese during processing. Food Res. Int. 27:61-64.

Gòmez-Cortés, P., A. Bach, P. Luna, M. Juarez, and M. A. de la Fuente. 2009. Effects of extruded linseed supplementation on n-3 fatty acids and conjugated linoleic acid in milk and cheese from ewes. J. Dairy Sci. 92:4122-4134.

Gonthier, C., A. F. Mustafa, D. R. Ouellet, R. Berthiaume, and H. V. Petit. 2005. Feeding micronized and extruded flaxseed to dairy cows: Effects on blood parameters and milk fatty acid composition. J. Dairy Sci. 88:748-756.

Gripon, J.-C., M. J. Desmazeaud, D. Le Bars, and J. L. Bergere. 1975. Etude du role des micro-organismes et des enzymes au cours de la maturation des fromages. Lait 548:502-515.

Ha, Y. L., N. K. Grimm, and M. W. Pariza. 1989. Newly recognized anticarcinogenic fatty acids: identification and quantification in natural processed cheeses. J. Agric. Food Chem. 37:75-81.

IDF (International Dairy Federation). 1986. Cheese and processed cheese products. Determination of dry matter. FIL-IDF Standard No. 4. IDF, Brussels, Belgium.

IDF (International Dairy Federation). 2002. Milk fat-Preparation of fatty acid methyl esters. International standard ISO 15884- IDF 182:2002. IDF, Brussels, Belgium.

Kennelly, J. J. 1996. The fatty acid composition of milk fat as influenced by feeding oilseeds. Anim. Feed Sci. Technol. 60:137-152.

Lessard, M., N. Gagnon, and H. V. Petit. 2003. Immune response of postpartum dairy cows fed flaxseed. J. Dairy Sci. 86:2647-2657.

Lucas, A., E. Rock, J. F. Chamba, I. Verdier-Metz, P. Brachet, and J. B. Coulon. 2006. Respective effects of milk composition and the cheese-making process on cheese compositional variability in components of nutritional interest. Lait 86:21-41.

Lucey, J., and J. Kelly. 1994. Cheese yield. J. Dairy Technol. 47:1-14.

Luna, P., J. Fontecha, M. Juarez, and M. A. de la Fuente. 2005. Changes in the milk and cheese fat composition of ewes fed commercial supplements containing linseeds with special reference to the CLA content and isomer composition. Lipids 40:445-454.

Martin, C., J. Rouel, J. P. Jouan, M. Doreau, and Y. Chilliard. 2008. Methane output and diet digestibility in response to feeding dairy cows crude linseed, extruded linseed, or linseed oil. J. Anim. Sci. $86: 2642-2650$.

Mele, M., G. Contarini, L. Cercaci, A. Serra, A. Buccioni, M. Povolo, G. Conte, A. Funaro, S. Banni, G. Lercker, and P. Secchiari. 2011 Enrichment of Pecorino cheese with conjugated linoleic acid by feeding dairy ewes with extruded flaxseed: Effect on fatty acids and triglycerides composition and on oxidative stability. Int. Dairy J. $21: 365-372$

NRC. 2001. Nutrient Requirements of Dairy Cattle. 7th rev. ed. National Academy Press, Washington, DC.

Nudda, A., M. A. McGuire, G. Battacone, and G. Pulina. 2005. Seasonal variation in conjugated linoleic acid and vaccenic acid in milk fat of sheep and its transfer to cheese and Ricotta. J. Dairy Sci. 88:1311-1319.

O'Fallon, J. V., J. R. Busboom, M. L. Nelson, and C. T. Gaskins. 2007. A direct method for fatty acid methyl ester synthesis: Application to wet meat tissues, oils, and feedstuffs. J. Anim. Sci. $85: 1511-1521$.

Petit, H. V. 2010. Review: Feed intake, milk production and milk composition of dairy cows fed flaxseed. Can. J. Anim. Sci. 90:115-127.

Petit, H. V., C. Germiquet, and D. LeBel. 2004. Effect of feeding whole unprocessed sunflower seed and flaxseed on milk production, milk 
composition, and prostaglandin secretion in dairy cows. J. Dairy Sci. 87:3889-3898.

SAS Institute. 2011. SAS User's Guide: Statistics. Version 9.2 ed. SAS Inst. Inc., Cary, NC.

Shantha, N. C., E. A. Decker, and Z. Ustunol. 1992. Conjugated linoleic acid concentration in processed cheese. J. Am. Oil Chem. Soc. 69:425-428.

Shapiro, S. S., and M. Wilk. 1965. An analysis of variance test for normality. Biometrika 52:591-611.

Shingfield, K. J., Y. Chilliard, W. Toivonen, P. Kairenius, and D. I. Givens. 2008. Trans fatty acids and bioactive lipids in ruminant milk. Pages 3-65 in Bioactive Component of Milk: Advances in Experimental Medicine and Biology. Vol. 606. Z. Bösze, Ed. Springer, New York, NY.
Simopoulos, A. P. 1996.Omega-3-fatty acids and public health. Pages 5-28 in Proc. Flax Council of Canada Conf. Flax, the Next Decade, Winnipeg, MB, Canada.

Ulbricht, T. L. V., and D. A. T. Southgate. 1991. Coronary heart disease: Seven dietary factors. Lancet 338:985-992.

Williams, C. M. 2000. Dietary fatty acids and human health. Ann. Zootech. 49:165-180.

Wright, T., B. McBride, and B. Holub. 1998. Docosahexaenoic acidenriched milk. World Rev. Nutr. Diet. 83:160-165.

Zhang, R., A. F. Mustafa, and X. Zhao. 2006. Effects of flaxseed supplementation to lactating ewes on milk composition, cheese yield, and fatty acids composition of milk and cheese. Small Rumin. Res. 63:233-241. 